In Situ

Revue des patrimoines

\section{In Situ}

Revue des patrimoines

$28 \mid 2016$

Le moulage. Pratiques historiques et regards contemporains

\title{
The Gherardis Castmakers in Paris and Rome
}

Peter Malone

\section{(2) OpenEdition \\ Journals}

Electronic version

URL: http://journals.openedition.org/insitu/12712

DOI: 10.4000/insitu. 12712

ISSN: 1630-7305

Publisher

Ministère de la culture

Electronic reference

Peter Malone, "The Gherardis Castmakers in Paris and Rome », In Situ [En ligne], 28 | 2016, mis en ligne le 15 mars 2016, consulté le 03 mai 2019. URL : http://journals.openedition.org/insitu/12712 DOI : 10.4000/insitu. 12712

This text was automatically generated on 3 May 2019.

\section{(c) (i) (3)}

In Situ Revues des patrimoines est mis à disposition selon les termes de la licence Creative Commons Attribution - Pas d'Utilisation Commerciale - Pas de Modification 4.0 International. 


\title{
The Gherardis Castmakers in Paris and Rome
}

\author{
Peter Malone
}

Acknowledgements are due to Deirdre Westgate and Julia Owen for visiting various archives, on my behalf, in Paris and Rome respectively; James Sutton at The Victoria \& Albert Museum Archives, and Jean-Marc Hofman at the musée des Monuments français, Paris, who has generously allowed me to use parts of his own research.

Contribution complémentaire aux Actes des journées d'étude « Le moulage. Pratiques historiques, regards contemporains » (Cité de l'architecture et du patrimoine/musée du quai Branly, 14\&15 novembre 2012)

1 Michele Gherardi was born on the $29^{\text {th }}$ October 1837 at Borgo a Mozzano, Lucca and christened Giovanni Michele Innocenzo at the church at nearby Granaiola. Although the parish register does not record his father, Serafino's, occupation, a document issued for Michele's marriage with Clelia Batocchi, at Marino, near Rome, in 1874, accords him the position of 'possidente', landowner'. It is therefore possible that Michele was the first of his immediate family to become a castmaker. The parish register also records that in 1853 he went abroad $^{2}$. In all probability this was to take up a prearranged apprenticeship with the castmaker Giuseppe Barsugli, whose workshop was then at 15 rue Racine, Paris. As Barsugli was born at Piano della Rocca, two kilometres north of Borgo, it is likely that there was a connection between the families ${ }^{3}$.

Barsugli is a most uncommon name. Out of five US immigration records that I could find for the end of the nineteenth century and the beginning of the twentieth, the four Barsuglis that did state their precise origin all came from Borgo or Piano della Rocca. A probable reference to Giuseppe's presence in Paris is provided by a newspaper report of 1832, wherein a certain Barsugli and his fellow castmaker Paccini were accused of infringement of copyright ${ }^{4}$. Most curious, however, is the presence in Copenhagen censuses of 1840, 1845 and 1850 of a Giuseppe Barsugli, castmaker, born at Lucca ${ }^{5}$. His implied dates of birth vary on each entry and could therefore have been at any time from 
1801 to 1803 . The Paris Barsugli was born either, (according to his death certificate) in 1803 or 1804 or (according to his marriage record) in 1804 or $1805^{6}$. Just as spellings of names vary considerably in the official records of these times, so do ages and the years of birth that one is able to deduce from them. It is a bizarre coincidence that there could have been two different castmakers called Giuseppe Barsugli, both born around 1803 in the Duchy of Lucca, each working in different places. The Paris Barsugli appears in DidotBottin, under the heading 'Mouleurs' from 1847 onwards. In 1850, the Copenhagen Barsugli was apparently living apart from his Danish family who are not to be found elsewhere in the census. The Paris Barsugli married Anne Montillon at the church of St. Sulpice in 1849. Were they one and the same? In the absence of further information, one can only speculate. A directory for Lubeck, Germany, 1873, records a Luigi Barsugli, 'gypsfigurenfabrikant' living at 338 Fischergrube 7 .

3 From around 1855, Barsugli's workshop was at 45 rue Monsieur le Prince, in the $6^{\text {th }}$ arrondissement ${ }^{8}$. He died there on the $4^{\text {th }}$ January $1860^{9}$. He was survived by his widow, Anne Montillon and a child, Augustine Georgette Barsugli, born $25^{\text {th }}$ December $1855^{10}$. A signatory to Barsugli's passing was Jean Funai, mouleur, possibly one of his employees, who would later work for the firm of Brucciani, at London ${ }^{11}$. The twelve year lease of the premises (and presumably the running of the business) was taken out in the joint names of Michele Gherardi and Anne Montillon, on the $12^{\text {th }}$ July $1860^{12}$. This arrangement took a more intimate turn when they married in $1862^{13}$. Until then Gherardi had been living at 53 rue M. le Prince. Contrary to the parish register at Granaiola, the marriage certificate gives his date of birth as $29^{\text {th }}$ December 1837; both his and Anne's occupations are given as mouleur. Serafino Gherardi, his father, is here described as a 'propriétaire'. Anne Montillon died $8^{\text {th }}$ October 1867 , age $43^{14}$. On the death certificate Gherardi's occupation is given as sculptor. A signatory to the document, Erigo Gherardi, is described as the deceased's brother in law. I could find no children from this marriage. 
Figure 1

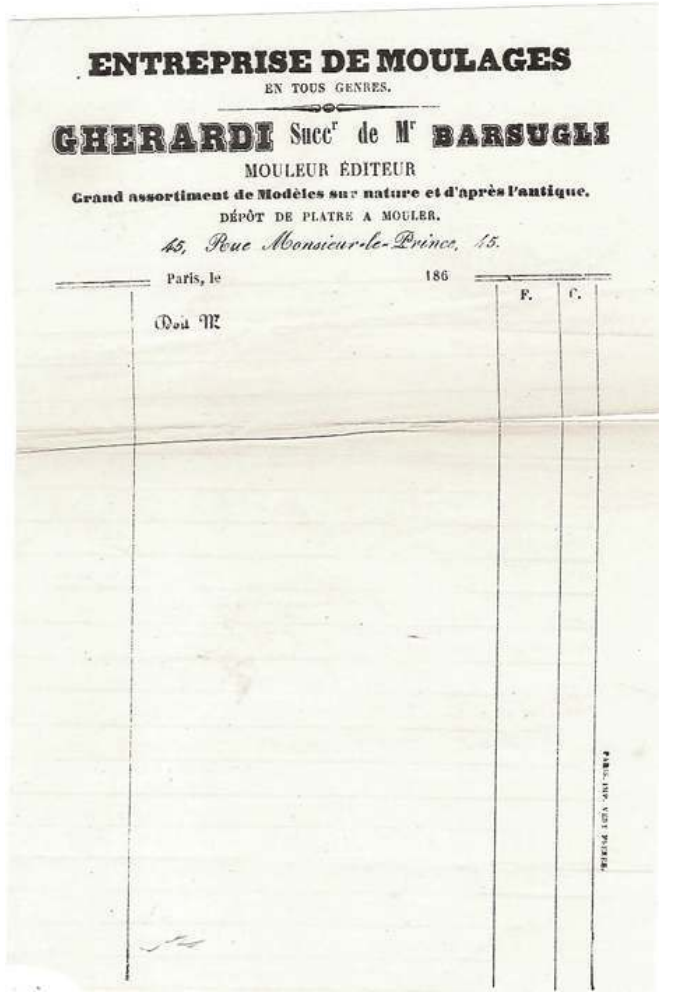

UNUSED GHERARDI INVOICE, 1860s.

(C) PETER MALONE.

4 A blank invoice printed for use in the 1860s is headed 'Entreprise de Moulages en tous genres. Gherardi Successeur de M. Barsugli. Mouleur éditeur. Grand assortiment des modèles sur nature et d'après l'antique. Dépôt de plâtre à mouler, 45 rue Monsieur le Prince' (fig. 1). Such casts are exemplified by three photographs owned by the École nationale supérieure des beaux-arts, presumably promotional material supplied by Gherardi himself (fig. $\mathbf{2}, \mathbf{3}, \mathbf{4}$ ). The casts are small to medium size, suitable for academic study and little different to what many another reputable castmaker had to offer at this time. Many of them must have come from Barsugli's collection of moulds. Another invoice heading adds to the information quoted above, '...médaillé à l'Exposition de Lucca (Italie) ${ }^{115}$. This must be a reference to the exhibition of 1869 when both he and Jean Pouzadoux were awarded bronze medals ${ }^{16}$. 
Figure 2

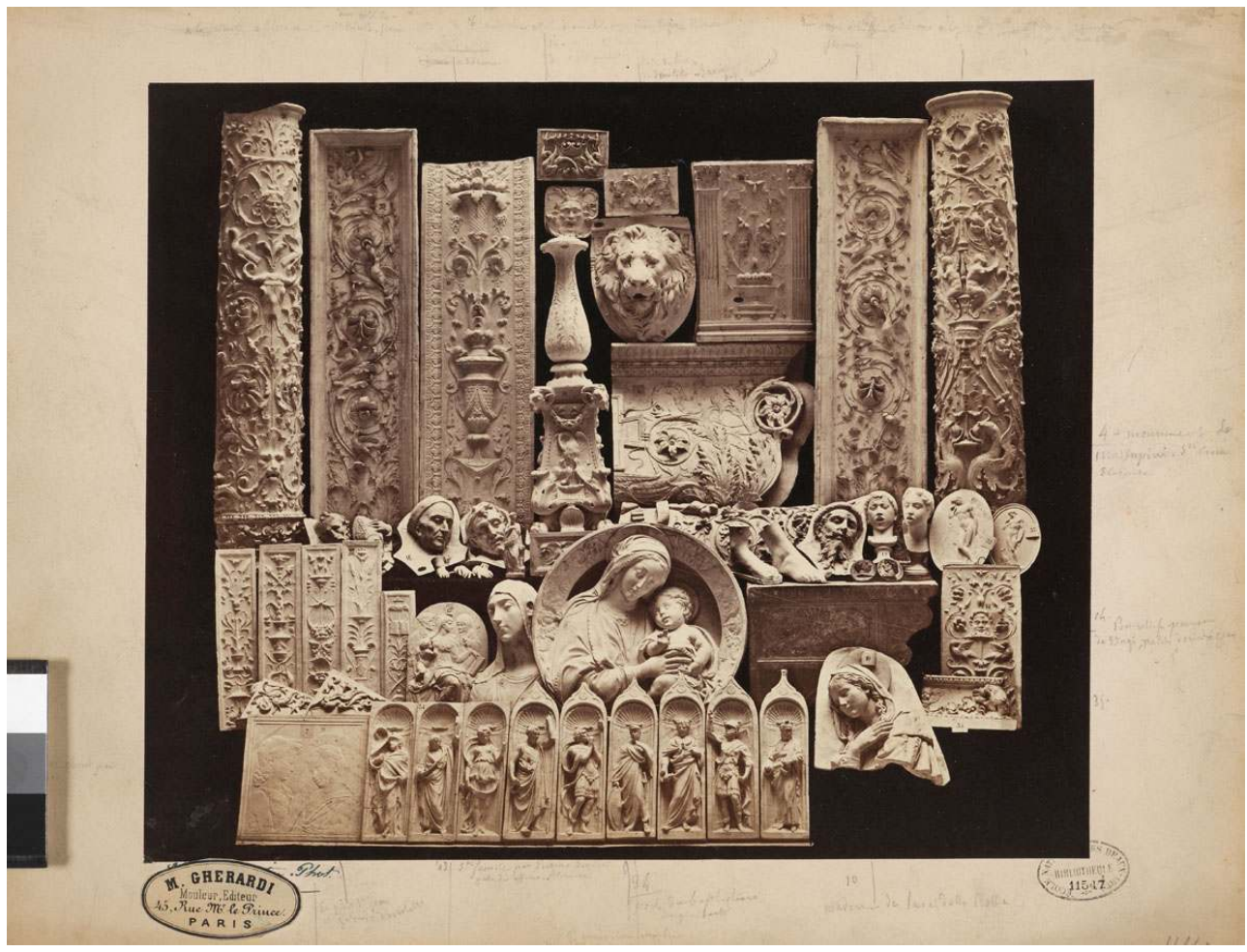

Plastercasts after Gherardi, anonymous.

(c) Beaux-Arts de Paris, Dist. RMN-Grand Palais/image Beaux-Arts de Paris. 
Figure 3

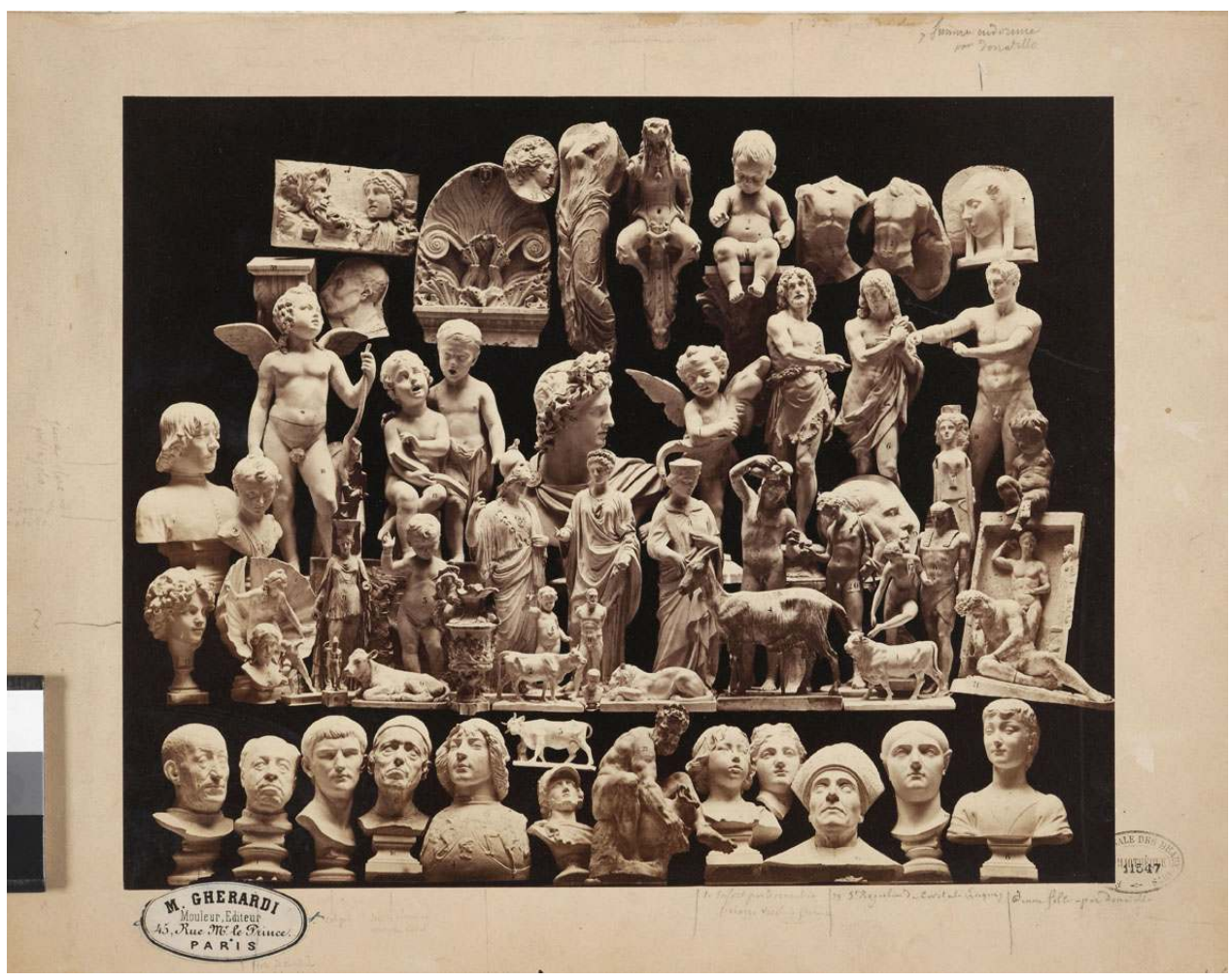

Plastercasts after Gherardi, anonymous.

(c) Beaux-Arts de Paris, Dist. RMN-Grand Palais/image Beaux-Arts de Paris. 
Figure 4

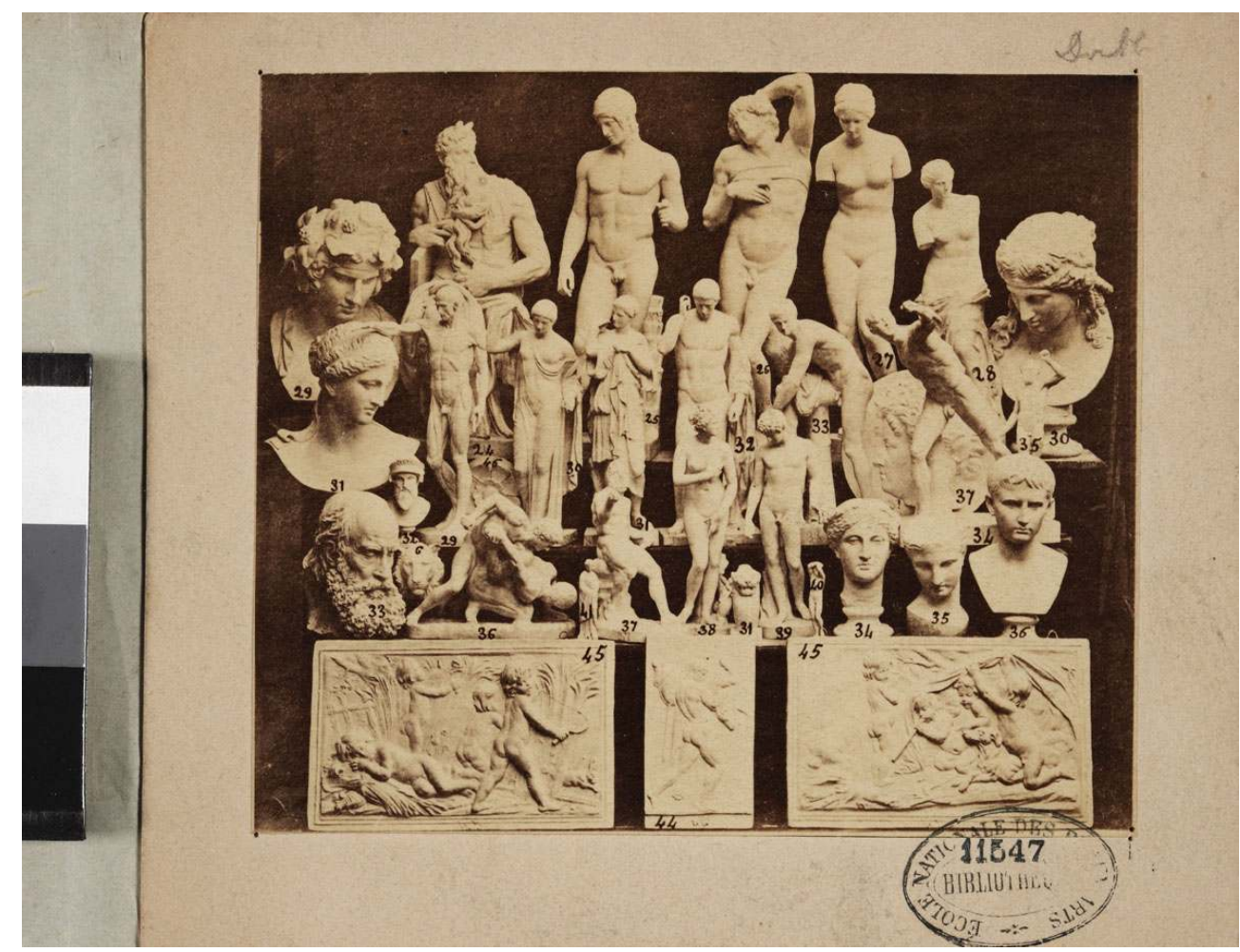

Plate for the sale of the Gherardi workshop; Anonymous.

(C) Beaux-Arts de Paris, Dist. RMN-Grand Palais/image Beaux-Arts de Paris.

5 From 1875, the premises at 45, rue Monsieur le Prince were in the name of Pouzadoux, long term associate of Adolphe Geoffroy-Dechaume, and first castmaker to the Musée de Sculpture Comparée. An oval, metal plaque (fig. 5), from a small ornamental relief, shows both the names of M. Gherardi and Pouzadoux. The Musée Bonaparte at Auxonne has two casts made from designs by Charles Normand which carry the stamps of both men ${ }^{17}$. 


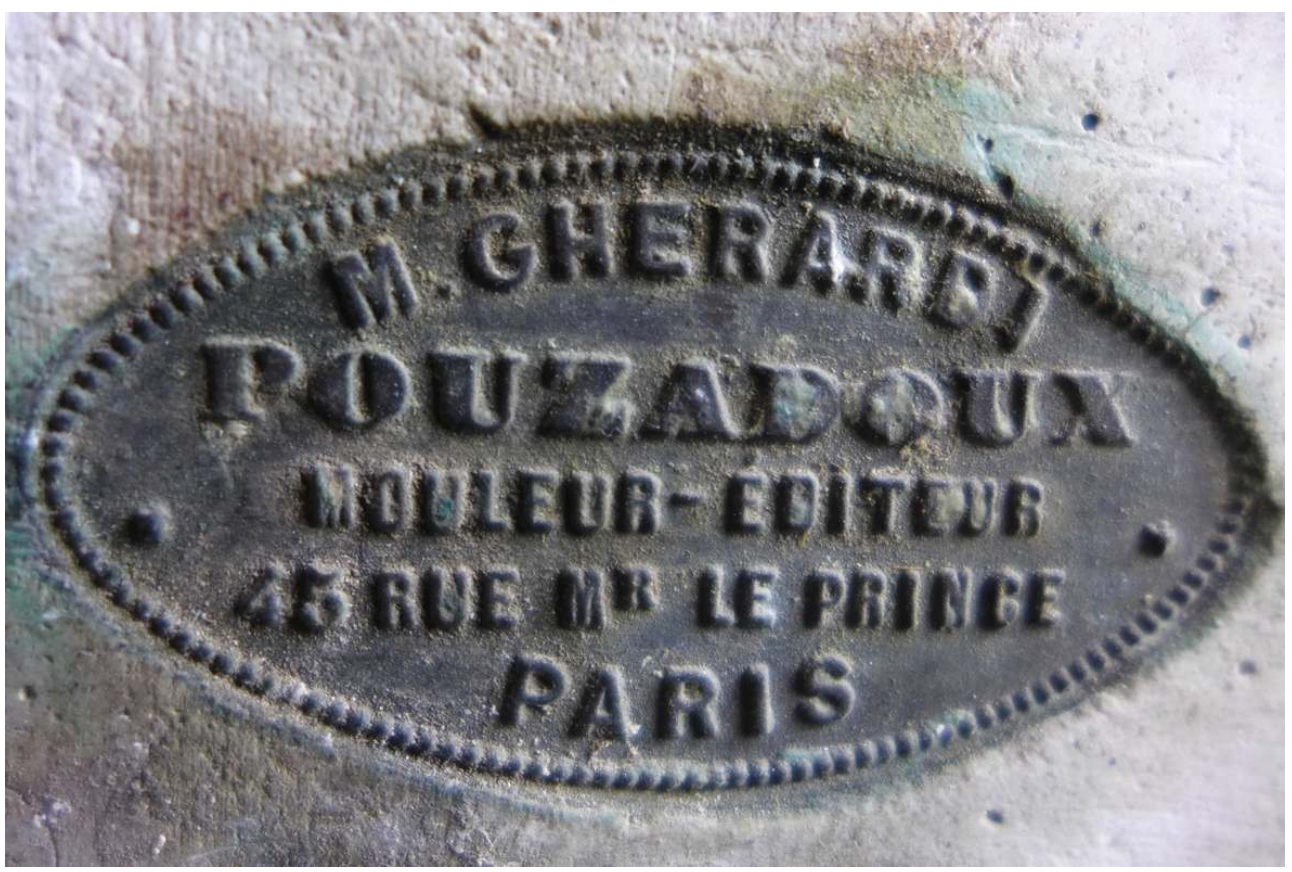

METAL STAMP BEARING THE NAMES OF BOTH POUZADOUX AND GHERARDI.

(C) PETER MALONE.

This raises the probability that there was a partnership between them that could have resulted in a number of casts. In 1879 and 1880 Gherardi is listed in Didot-Bottin as having premises at 3 rue Fontaine [Pierre-Fontaine] in the $9^{\text {th }}$ arrondissement. This address is cited in the 1877 marriage document of Hilaire Antoine Gherardi, age twenty eight, entrepreneur de moulages, with Rose Mayeux ${ }^{18}$. Hilaire was born at Borgo a Mozzano. His father was Gherardo Gherardi, then living at Granaiola but, more interestingly, his mother was Petronilla Gabrielli. From 1882 to 1897, a shop at 43 rue de Constantinople was in Gherardi's name. Thereafter, until at least 1933, it was in the name of Charles Gabrielli. Once again it is possible that he and Gherardi had a similar arrangement to that previously enjoyed with Pouzadoux, as indicated by inscriptions on a cast of citrus fruit (fig. 6). From 1897 to 1904 , Gherardi had a shop at number 12 in the same street ${ }^{19}$. 
Figure 6

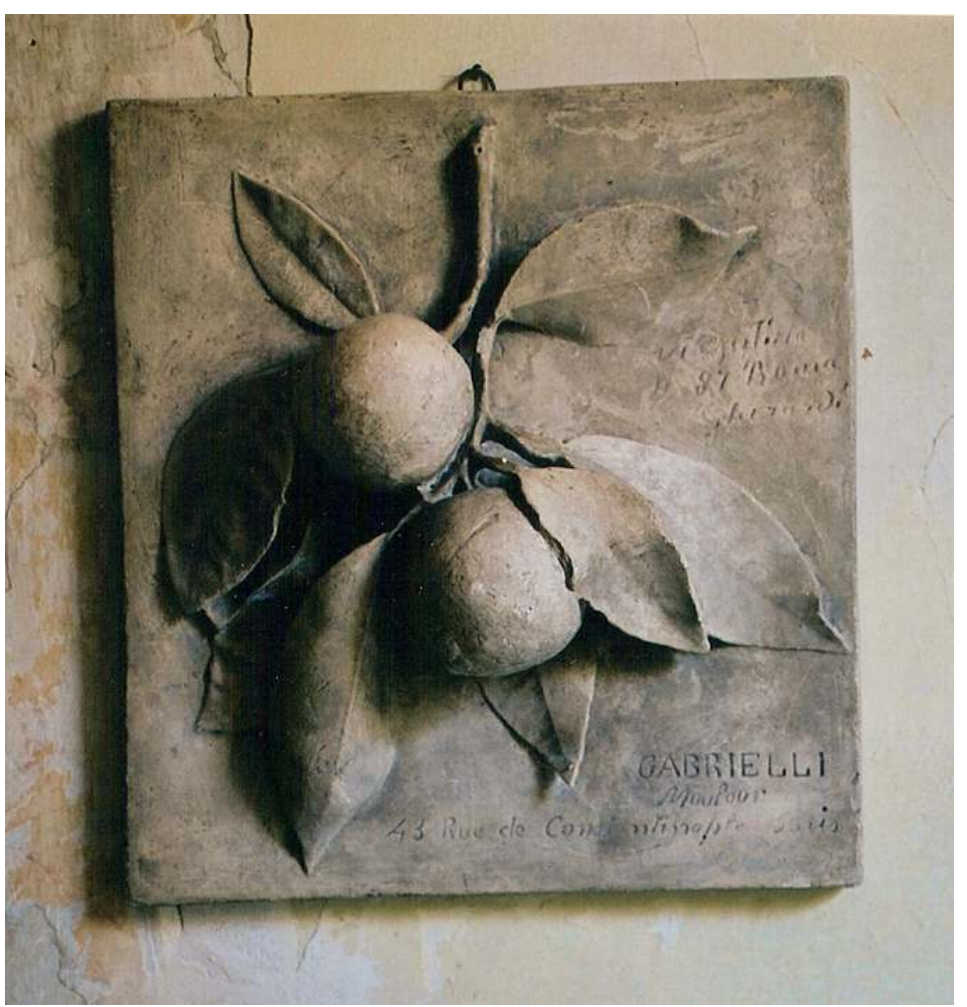

INSCRIBED ARE THE ADDRESSES OF GABRIELLI AT 43 RUE DE CONSTANTINOPLE AND GHERARDI AT VIA SISTINA 87. THIS CAST ALSO APPEARS IN THE 1911 CATALOgUE OF THE BOSTON CASTMAKER CAPRONI WHERE THE FRUIT ARE DESCRIBED AS MERANgOLI.

(c) PETER MALONE.

7 Angelo Pellegrini's 1869 Rome guide lists the following 'Formatori in gesso': Leopoldo Malpieri at Via del Corso 54; Fillipo and Alessandro Malpieri at number 51, same street. Marsili Fratelli at Via due Macelli 86 and Giuseppe Marsili at numbers 9 and 10 Via Frattina ${ }^{20}$. The Malpieri family had been at the centre of castmaking at Rome since the end of the eighteenth century. It is known that they worked for the French academy, for Canova and, more than likely, for other sculptors. The Fratelli Marsili firm began in $1850^{21}$ . Can this mean that there were then only four operatives from two families at work in Rome or were these the only ones that paid for inclusion in the directory, or were selected as worthy by the editor? Earlier and later, $19^{\text {th }}$ century directories, (or perhaps one should more properly call them guidebooks), list no more than five Roman castmakers at any one time. In 1869, Didot Bottin lists forty two mouleurs in Paris. Cast production here, and indeed at London, relied heavily on surmoulage, repeating what others had already moulded. Rome, however, was the prime source for much classical material; any cast of a sculpture, which could have been copied five times before it had travelled halfway around the world, could be moulded directly from the original at Rome; that is if permission was granted ${ }^{22}$. In Tito Monaci's guide book, Guida Scientifica, Artistica e Commerciale della Citta di Roma, 1871, the name of F. Gherardi can be found on page 215 under the heading Formatori in Gesso. The address, Via Sistina 87 is subsequently associated with Michele Gherardi. Given F Gherardi's absence from previous catalogues, was his business newly started or had it simply not been included? This is the only Reference I have been able to find for this castmaker who was undoubtedly related to 
Michele, probably a brother, cousin or uncle ${ }^{23}$. Michele's business at Paris, having survived the upheavals of the Commune, was probably doing well enough. It is recommended in William T Brigham's book, Cast Catalogue of Antique Sculpture (Boston 1874), among a worldwide list of eighteen castmakers.

8 It is possible that F. Gherardi sent casts from Rome to Paris. This would have been facilitated by the completion, in 1872, of a direct rail link via the Ligurian coast. Before then, casts made at Rome would have to undertake a long and hazardous sea voyage to their destination. His subsequent absence from the records might explain how Michele came to be in Rome by 1873 (See endnote 15) thus becoming the only $19^{\text {th }}$ century castmaker known to have had businesses in both cities. By 1874 he was sufficiently established at Rome to embark on his second marriage, to Clelia Batocchi. On the marriage banns, his age is given as 36 (thus endorsing the Granaiola birth record), and his occupation as sculptor ${ }^{24}$. As the status of the bride's father was possidente, landowner, it would seem that no professional advantage could have come from this match. Clelia died three years later; once again, I could find no record of children from this marriage. Sometime before 1886, he married for the third time, to Ersilia Marsili (1852-1936) of the castmaking family of that name; this might well have helped him commercially ${ }^{25}$.

In 1883 the Istituto d'Arte di Firenze acquired a dozen or so, medium size casts of architectural details from Gherardi. These had been sourced, from among other places, the Vatican, the Villa Medici, the Lateran museum, the Ara Pacis Augusti Museum and the Uffizi; he had either been allowed direct access to the originals or had come to an arrangement with another Rome castmaker ${ }^{26}$. A catalogue from his workshop at Via Sistina 87, from the early 1890s, contains 181 casts, sourced from the Vatican (including The Nile and Ariadne sleeping), the Museums of the Campidoglio and Lateran; Villas Medici, Madama, Borghese and Adriana; large architectural details from the Pantheon, the Foro Romano and other Roman monuments. These and others found their way to museum cast collections, university archaeological departments, art schools and probably other castmakers across Europe and beyond (fig. 7). 
Figure 7

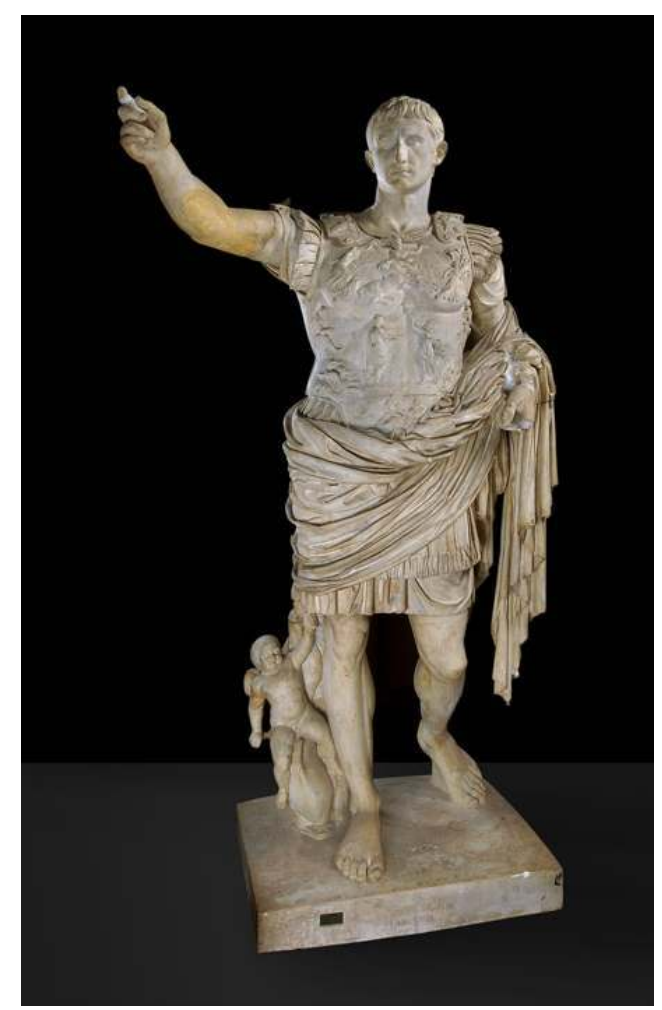

GHERARDI'S CAST OF AUgUSTUS PRIMA PORTA (CG:B-161), AT THE CAST GALLERY OF THE ASHMOLEAN MUSEUM, OXFORD.

(C) ASHMOLEAN MUSEUM, UNIVERSITY OF OXFORD.

10 Evidently he was running a large establishment capable of producing large, good quality casts. A letter heading of 1896, covering the delivery of fourteen casts to the Staatliche Kunstsammlungen, Dresden declares Gherardi to be 'Formatore del Governo Italiano e di alcuni altri governi filiale', as well as providing the addresses of Via Sistina 87, rue de Constantinople 43 and Via della Purificazione $73^{27}$. Judging by its appearance, the building at this last address must have been workshop space. Intriguingly, a stone plaque high on the wall carries the inscription 'Bernardi Gherardi. Libera ab omni onere' (fig. 8). This is Latin not Italian and translated, possibly reads 'Of Bernardo Gherardi, free from all burdens'. The Latin hints at a church connection; official state notices would surely have been in Italian after 1870? Who, if anyone, was Bernardo Gherardi and what does it actually mean? Could this refer to another relative of Michele, resident at Rome before him? 


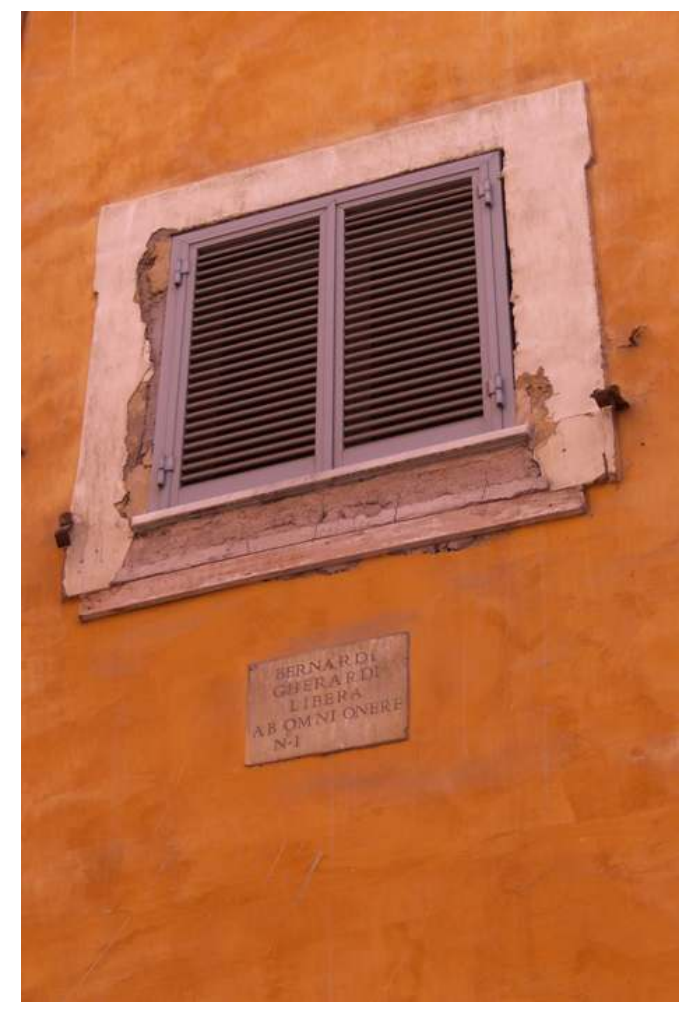

THE ENIgMatic PLAQUe AT VIA DELLA PURIficAzIONE 73.

(C) PETER MALONE.

11 Notification of a Medal of Honour from the Ministry of Agriculture, Industry and Commerce graces a promotional flyer of 1898 sent to the archaeological Institute of Gottingen University ${ }^{28}$ : Also provided is another address, Via Sistina 56. In this, Gherardi offers for 200 lire, an Apollo taken from the Tiber in 1891 and recently moulded by him. In 1904 his premises were at Via Sistina 46a. The catalogue from this address announces casts of architecture, sculpture and ornament from Egypt, Greece, Etruria, Rome and Italy. Also here is his status as provider of casts to the Ministry of Education in Italy and of various foreign governments. Within, 247 items are listed. From what I have seen of his catalogues I presume that they do not provide a comprehensive account of his entire stock. Rather, they appear on an ad hoc basis, differing in size and format, sometimes being little more than an individual sheet advertising a new set of casts. Illustration is sparse, being restricted to the opening page, if at all. The items are accorded numbers, but these apply only to a particular catalogue and are there purely to be quoted by the purchaser. They exclusively cover the medium size and large casts; I have yet to find a catalogue that deals with smaller items; possibly there were none. Interesting, though perhaps not conclusive, comparisons can be made between catalogues of Gherardi and Leopoldo Malpieri from the early 1890s. Their sources are, for the most part, different: for example, there are twenty one casts from the Museo Capitolino in the Malpieri catalogue and none in Gherardi's. Even where they share common ground, as in the Vatican collections, there is little overlap between them but where this does happen, the prices are identical. These catalogues are selective of either firm's general output but could there have been an agreement not to cast the same objects and where this was unavoidable, to do so at the same prices? 
The Guida Commerciale, Scientifica ed Artistica di Roma, 1900, under the heading 'Formatori e ornatisti in gesso e scagliola', lists Gherardi Fratelli at Via Sistina 56. A letter from the firm of Gherardi, sent to The Victoria and Albert Museum, dated $8^{\text {th }}$ November 1904, signed by Stefano Marsili, informs the Museum of the death of Michele ${ }^{30}$. This happened on the $27^{\text {th }}$ of August at Via Purificazione 38. His occupation is given as negoziante and his age (wrongly) as 73. Witness to the formalities was provided by Stefano Marsili and Augusto Bertaccini, formatori ${ }^{31}$. The firm was then run by his son, Virgilio Gherardi (1886-1941 ${ }^{32}$. An invoice dated $20^{\text {th }}$ September 1912, sent to the Archaeology department of Göttingen University, for the supply of casts of the Vecchio Pescatore and a contadina, shows the firm's address as 76 Via della Lungaretta, in Trastevere. The heading informs us that he is the successor to both the firms of his father and of Leopoldo Malpieri. Also that his casts are taken from the original ('forma sul vero') and that he is castmaker to the national museums and all the significant academies at Rome. Having incorporated the firm of his closest rival and long since forged links with a branch of the Marsili family, Ditta Gherardi had become the most significant castmakers there. According to his granddaughter, Chiara Gherardi, he had workshops at the Baths of Diocletian (Museo Nazionale Romano) and that after his death, everything connected to his work passed to the Italian State ${ }^{33}$. I do not know when the firm came to an end; presumably, like many others, at some time during or after the Great War, when casts were required by neither museums nor schools of art. The latest date that I could find for the firm is $1914^{34}$.

Though my findings are far from complete, especially where Virgilio and F. Gherardi are concerned, I hope that there is enough material here that might provide a foundation for further research of this subject. Gherardi was one of the major castmakers of the $19^{\text {th }}$ century; many of his casts survive in various collections around the world. The same can also be said for the many members of the Malpieri family who merit further investigation. Should anyone wish to contact me about anything written above, my address is info@petermaloneillustration.com

\section{Biography}

Peter Malone has taught drawing at an English art school and worked as an illustrator for the last twenty years. He has written the most authoritative account, to date, on the plaster death masks of the poet John Keats (for the Keats Shelley Review), contributed an essay on the London castmakers, Charles Smith and Sons for 'Plaster Casts: Making, Collecting and Displaying from Classical Antiquity to the Present', De Gruyter, 2010 and has provided an article on the Paris castmakers, Lorenzi, for World of Interiors Magazine. 


\section{NOTES}

1. - Ufficio dello Stato Civile, Comune di Marino, Richiesta per pubblicazione di Matrimonio, $\mathrm{n}^{\circ}$ 54, $2^{\text {nd }}$ February, 1874. A personal communication from Rossella Gherardi, great-granddaughter of Michele, mentions a sizeable estate at Bagni di Lucca that passed to another branch of the family.

2. - Letter from Don Lorenzo Nanni, parish priest, Church of San Michele, Granaiola, Lucca, $24^{\text {th }}$ February 2007.

3. - Département de la Seine, Ville de Paris, $6^{\text {th }}$ arrondissement, registre double des actes de décès, $4^{\text {th }}$ January 1860 (archives de la Ville de Paris, V4E 636).

4. - Gazette des Tribunaux, Paris, p. $443,26^{\text {th }}$ February 1832. Information from Jean-Marc Hofman.

5. - All three censuses mentioned were conducted on the $1^{\text {st }}$ of February.

6. - Fichier des mariages parisiens, 1795-1862, vol. 11, p. 44, Joseph Barsugli with Anne Montillon, $28^{\text {th }}$ July 1849 (archives de la Ville de Paris, V3E/M42).

7. - Verein fur Computergenealogie, Lubeck address book, 1873. Verein fur Computergenealogie, Lubeck address book, 1873 [consulted on $16^{\text {th }}$ March 2016].

8. - Annuaires-Almanachs du Commerce, Didot-Bottin, under the heading 'Mouleurs-figuristes'. All such addresses in this article, unless otherwise stated, ultimately derive from this source.

9. - Op. cit.

10. - Information from Jean-Marc Hofman.

11. - A mould, signed by him, is retained at the British Museum store.

12. - Archives de Paris, archives fiscales, calepins des propriétés bâties, 1852-1876, cadastre de 1852, D1P4 734 \& 744.

13. - Département de la Seine, Ville de Paris, $6^{\text {th }}$ arrondissement, registre double des actes de mariage pour l'année 1862, $\mathrm{n}^{\circ} 160,1^{\text {st }}$ March 1862, Michele Gherardi with Anne Montillon (Arch. Paris, V4E 658). Anne was born $3^{\text {rd }}$ November 1822 at Dun-le-Roi (Cher).

14. - Département de la Seine, Ville de Paris, $6^{\text {th }}$ arrondissement, registre double des actes de décès pour l'année 1867, $\mathrm{n}^{\circ}$ 2153, Montillon, femme Gherardi (archives de Paris, V4E 728).

15. - RIONNET, Florence. L'atelier de moulage du musée du Louvre (1794-1928). Paris : Réunion des musées nationaux, 1996, p. 378. In this entry the move to Rome is recorded as happening in 1873: 'ateliers et magasins à Rome, 87 Via Sistina...'

16. - HOFMAN, Jean-Marc. «Rencontre avec un illustre inconnu. Jean Pouzadoux (1829-1893), mouleur en plâtre ». Bulletin de la société historique du $6^{e}$ arrondissement, $\mathrm{n}^{\circ} 24,2011$.

17. - Perhaps the easiest means of viewing these casts is to enter on the net, the search term 'Gherardi Pouzadoux Auxonne'. On the Joconde database: http://www.culture.gouv.fr/public/ mistral/joconde_fr?

ACTION=RETROUVER\&FIELD_98=APTN\&VALUE_98=Auxonne\&NUMBER=22\&GRP=0\&REQ=\%28\%

28Auxonne\%29 \%3aAPTN \%29\&USRNAME=nobody\&USRPWD $=4 \% 24 \%$

$34 \mathrm{P} \& \mathrm{SPEC}=3 \& \mathrm{SYN}=1 \& \mathrm{IMLY}=\& \mathrm{MAX} 1=1 \& \mathrm{MAX} 2=1 \& \mathrm{MAX} 3=200 \& \mathrm{DOM}=$ All $\quad$ et $\quad \mathrm{http}: / /$

www.culture.gouv.fr/public/mistral/joconde_fr?

ACTION=RETROUVER\&FIELD_98=APTN\&VALUE_98=Auxonne\&NUMBER=23\&GRP=0\&REQ=\%28\%

28Auxonne\%29\%20\%3aAPTN\%20\%29\&USRNAME=nobody\&USRPWD $=4 \% 24 \%$

$2534 \mathrm{P} \& \mathrm{SPEC}=3 \& \mathrm{SYN}=1 \& \mathrm{IMLY}=\& \mathrm{MAX} 1=1 \& \mathrm{MAX} 2=1 \& \mathrm{MAX} 3=200 \& \mathrm{DOM}=$ All $\left[\right.$ consulted $\quad$ on $16^{\text {th }}$ March 2016].

18. - Archives de Paris, mariages, $9^{\text {th }}$ arrondissement, vol. $4 \mathrm{E}, \mathrm{n}^{\mathrm{o}} 3545, \mathrm{p} .29$. Information supplied by Jean-Marc Hofman. 
19. - Victoria and Albert Museum Archives, file MA/1/G475. The address appears on a letter heading from the firm of Gherardi, dated $8^{\text {th }}$ November 1904, advising of the death of Michele, signed by Stefano Marsili. On a letter in the same file, written $22^{\text {nd }}$ May 1905, the address is crossed out.

20. - PELLEGRINI, Angelo. Itinerario o Guida Monumentale di Roma, Antica e Moderna e suoi dintorni. Rome: Vincenzo Sciomer, 1869, under the heading Formatori in Gesso.

21. - Giovanna Marsili may be found online as president of the association 'Eredi ditta Fratelli Marsili, casa fondata nel 1850'. In an online response to an exhibition of the castmakers' art, held at Lucca, in May 2013 ("L'Accademia lucchese e i formatori di gesso - il patrimonio della Gipsoteca Passaglia") she commented that she holds some three hundred casts, presumably from the family firm.

22. - No easy task. The V\&A Museum files MA/1V116 and RP/1896 23339 contain correspondence, commencing in May 1896, concerning the commission of a mould of the sarcophagus of Junius Bassus, at the Vatican. Other than the V\&A, this involved Cardinal Vaughan of Westminster cathedral, in the role of go-between, Felix-Marie de Neckère, titular archbishop of Melitene and secretary of the Fabric of the Basilica of St. Peter's, Alberto Galli, superintendant of art at the Vatican museums and his chosen formatore, Cesare Malpieri. Negotiations went on for a year, the final decision being that a mould could be taken but only in clay. Given the high relief of the figures on the sarcophagus, this would have been an immensely tedious operation. The sum required for this was quoted as 1,800 lire. At 800 lire more than the most expensive item currently in the Malpieri catalogue, it is little wonder that the V\&A decided that enough was enough and withdrew their interest.

23. - A search carried out by the current priest at Granaiola, Don Emanuele Rosi, in January 2015, for the years 1830 to ca. 1850 found only one possible candidate, Giuseppe Federico Gherardi, baptised $2^{\text {nd }}$ March 1848, son of Giustino and Maria Teresa Mariani. His godfather is named as Serafino, Michele's father. I am grateful to Luca Caddia at the Keats-Shelley House, Rome for acting as go-between.

24. - Op. cit.

25. - I chanced upon another example of such a union where Pietro Malpieri son of Leopoldo, married Giuditta Fideli daughter of castmaker Alessandro. (Ufficio dello Stato Civile, Rome, Pubblicazione di Matrimonio, 1873, Vol. 4, $\mathrm{n}^{\circ}$ 1213). Fideli is mentioned in the Baedeker guide to Rome, 1877, at Via Laurana 43, as a specialist in Renaissance ornaments, under the heading 'Castmakers'. According to present day Rome castmaker Andrea Felice, the fathers' workshops were in the same building.

26. - These are listed in BECATTINI, M., BERNARDINI, L., MASTROMATTEI, M. and MASTROROCCO, M. (eds.). Il Mondo Antico nei Calchi della Gipsoteca dell' Istituto d'Arte. Florence: SPES, 1992.

27. - Information sent by Dr. Kordelia Knoll, Dresden, $7^{\text {th }}$ February 2005.

28. - Information sent by Dr. Daniel Graepler, Göttingen, $10^{\text {th }}$ March 2005.

29. - Correspondance d'Hébert (2), nº 272, Gherardi à Hébert, Rome, ${ }^{\text {th }}$ April 1890, p. 195 (ou archives de l'Académie de France à Rome, 117 Hébert 2, fol. 508).

30. - Op. cit.

31. - Ufficio dello Stato Civile, Rome, Atto di Morte, 1904, $\mathrm{n}^{\circ} 3532$.

32. - Virgilio Gherardi, born $21^{\text {st }}$ January, 1886, died Rome $21^{\text {st }}$ March 1941. Information supplied by Rossella Gherardi, granddaughter, by email, $10^{\text {th }}$ September 2009.

33. - Personal communication sent $13^{\text {th }}$ February 2006.

34. - Letter from Tomas Lochman, Basel, $14^{\text {th }}$ April 2005. Five casts were acquired for the Skulpturhalle from 1909 to 1914. 


\section{ABSTRACTS}

An account of the Gherardi family, $19^{\text {th }}$ century castmakers with particular emphasis on Michele Gherardi from their commercial origins in Paris to international status at Rome, eventually merging with the long established firm of Malpieri.

INDEX

Keywords: Plaster cast, Castmaker, Gherardi, Barsugli, Pouzadoux, Malpieri, Marsili

AUTHOR

PETER MALONE

info@petermaloneillustration.com 